From Fast to Last:

The Japanese Economy in the 1990s

Kazuo Sato

Working Paper No. 187

Working Paper Series

Center on Japanese Economy and Business

Columbia Business School

May 2001 
From Fast to Last: The Japanese Economy in the 1990s

\author{
Kazuo Sato
}

\begin{abstract}
Japan is the first country that achieved the economic miracle of rapid growth. From stellar performance in the 1960s, it shifted to slow-growth (1975-90) but it still maintained the highest growth, and lowest inflation, among G7 economies. However, in the 1990s it had the lowest growth rate among the G7. This stagnation is due to three major factors. The first factor is the short-term reaction to the over-expansion of the economy in the late 1980s. The financial sector still is struggling with the aftermath of the bubble. The second factor is the on-going contraction of manufacturing. Manufacturing drove Japan's growth, especially productivity growth, but now employment is falling in that sector. The third factor is long-term changes in the population structure, specifically, the rapid aging of the population and the low level of the birth rate. All these changes have serious macroeconomic effects on the economy. If the Japanese economy is to be revitalized, an intensive and extensive overhaul is required, urgently. If Japan does not succeed at this task, its future will be dismal.
\end{abstract}




\section{From Fast to Last: The Japanese Economy in the 1990s}

\section{Kazuo Sato}

In the 1990s Japan has been last among the G7 as far as growth is concerned. This is in sharp contrast to its previous record. With the fastest growth and lowest inflation rate among G7 countries, Japan was the envy of other countries in the 1980s.

How has Japan moved from the top to the bottom of the G7? If the cause were simply a short-term reaction to the over-expanded economy of the late 1980s, brisk growth would have returned by now. However, there have been long-term changes in basic macroeconomic variables. This raises the possibility that Japan's economic system is not suited to the realities it faces. Indeed, there are many indications that Japan's economy, and even its society, is unravelling. If Japan is to revitalize itself, a drastic change is called for in its economic system, but there is strong resistance to such a move. This is Japan's dilemma.

The emergence and nature of this dilemma are explored in this essay. By way of context, the first section presents an overview of the past five decades. The 1990s are then reviewed more intensively, first on the real side, then on the financial side. The fourth section speculates on the future of the Japanese economy.

\section{Overview of Japanese Growth}

The last half of the 20th century can be divided into rapid-growth (1952-74), slow-growth (197590), and ultra-slow-growth (1990s) periods. 
By 1952, when the occupation of Japan came to an end, Japan had regained its prewar level of production. From then on, the economy stayed on a rapid-growth trajectory, especially in the 1960s when annual rates averaged a bit over 10\%. This "economic miracle" brought per capita real GDP from $30 \%$ of the US level in the early 1950 s to $60 \%$ by the end of the 1960 s. The first oil shock (1973-74), marked the transition from rapid growth to slow growth for Japan, as well as for other G7 countries. But, Japan still averaged a little over $4 \%$ annual growth during 1975-90. Per capita GDP had reached 80\% of the US level by 1990 .

The rapid-growth economy can be characterized as a full-employment economy of the neoclassical type, in which saving was in short supply and investment adjusted to it. The adjustment was made by a non-market mechanism: mainly government intervention. Japan consequently had a highly regulated economy.

By contrast, the slow-growth economy was Keynesian, with savings in excess supply. The government sought to manage aggregate demand so as to supplement investment. In this way, government continued to play a vital role in the economy.

Monetary policy was the primary vehicle for government intervention during the rapidgrowth period. The hyperinflation generated by liquidification of war bonds and government deficits after the war led to a policy of balanced budgets. This was codified in the 1947 Public Finance Act. Although a 1965 revision allowed the government in principle to issue "deficit bonds" if the need arose, this was not done until 1974. Instead, the central bank enforced a lowinterest policy, which set the bank loan rate below the free-market level at which savings and investment would be equated. The ceiling on the bank loan rate necessitated credit rationing among borrowers. This policy was effective because the bulk of savings was deposited in banks, which were strictly controlled by the economy's monetary authorities. 
Although the bank loan rate was low compared with the equilibrium rate, it was higher than the international level. However, borrowers could not borrow in foreign markets because of strict regulation of international capital flows, both in and out. This made Japan's macroeconomy highly regulated. The monetary authorities enforced credit rationing so as to allocate given saving to investing firms. In this way, saving determined investment, and this is how Japan's macro-economy was neoclassical.

Manufacturing led Japan's rapid growth, and exports of manufactured goods grew by leaps and bounds as industries, such as automobiles, became internationally competitive. Exports started to exceed imports by the mid 1960s, and Japan has continued to have export surpluses since.

1.1 The 1970 s and ' 80 s

By the early 1970s rapid growth had come to an end. Savings, however, continued to grow. Credit rationing was no longer needed. The ample supply of credit made banks willing to lend more generously, and borrowing firms responded by engaging in capital deepening. Thus, investment was kept up to the level of savings. Though growth was slowing, employment was over-full, as the supply of young labor was exhausted. In February 1973 the fixed exchange rate system ended, replaced by flexible rates, but Japan's trade surplus continued.

The 1973-74 oil shock pushed the economy into its first postwar recession with negative growth. Growth has never returned to its earlier levels: the economy found itself permanently slowed, from the $10 \%$ level of the 1960 s to the $5 \%$ level. 
The capital deepening of the early 1970s lowered the business profit rate. Low growth and low returns made business investment low. The private savings rate started to decline, but not as fast as business investment. The savings surplus in the private sector would have pushed the economy into a deep recession as Japan became a savings-abundant Keynesian economy. However, the country was rescued from this plight when, in 1975, the central government started engaging in deficit spending. Deficits reached 5.5\% of GDP in fiscal 1978. Fiscal policy was in active service during 1975-87.

Although the economy recovered from the oil shocks of 1973-74 and 1979-80, it was no longer as dynamic as in the rapid-growth period. In the early 1980s, it experienced its longest postwar recession (36 months, February 1980 to February 1983). Hence, the central bank decided to relax monetary policy.

In the early 1980s the US dollar was very expensive. This helped Japan's exports to expand, and the country's trade surplus continued to rise, reaching a peak of $4.0 \%$ of GDP in 1986. Japan was accumulating foreign exchange. Consequently, the money supply was growing at a high rate, faster than nominal GDP. This led to lower and lower interest rates.

To alleviate the adverse effect of the high US dollar on the US economy, the September 1985 Plaza Accord of the G5 countries took measures to make the dollar cheaper. The real value of the yen doubled in the next 3 years. To reduce the adverse effects of this on Japan, Japan's central bank lowered the discount rate, ultimately bringing it to a then-record low of $2.5 \%$ in February 1987. Government deficit spending ended. A surplus emerged in 1987 and peaked at 2.9\% of GDP in both 1990 and 1991.

This low-interest policy was accompanied by a rapid expansion of money and credit supplies. Easy money poured into asset markets, and the speculative demand for stocks and land 
sustained asset inflation. But it did not lead to inflation in the real economy. The run-up in asset prices made everyone happy: the late 1980s was a time of economic euphoria.

The central bank belatedly decided to shift from easy to tight money, and raised the discount rate sharply in May 1989, but money supply growth remained high in 1990. The stock market peaked in December 1989, land prices a year or so later.

\subsection{The $1990 \mathrm{~s}$}

In February 1991, what is called the Heisei recession started. It lasted 32 months, until October 1993. Money supply actually contracted in the fourth quarter of 1992 (at a $0.2 \%$ annual rate over the fourth quarter of 1991). The subsequent recovery was very anemic. One reason was the increasing weakness of the financial system.

With GDP growth at 5.1\% in 1996, the Ministry of Finance saw a vigorous recovery and moved to reduce the deficits with lower spending (especially government investment) and higher taxes in fiscal 1997. The timing was very poor, as the economy went into recession in March 1997.

The 1997-98 recession is Japan's severest in the postwar period, with a $2.5 \%$ contraction of GDP in 1998. Although officially recovered in April 1999, growth was just 0.5\% in the year ending March 2000. The labor market has remained very depressed, and the ratio of job offers to applications sank below the 0.50 level from August 1998 to November 1999, the lowest ever recorded from 1959 on. 
The last half of the 1990s was deflationary: the inflation rate was negative in 1995,1996 , and 1999, and barely above zero in 1997 and 1998. The Japanese media termed this "price destruction" (kakaku hakai).

The stock market, measured by the Nikkei, fell (albeit not steadily) from a December 1989 peak of $¥ 38,130$ to a trough of $¥ 13,487$ in October 1998 . Subsequently, it has traded in a $¥ 16,000-20,000$ range. The land price indexes have not stopped falling. In March 2000 the national average was $70 \%$ of its $1990-91$ peak, and the index for the six largest cities was just $35 \%$.

Neither monetary policy nor fiscal policy has proved effective in the 1990s, and Japan ended the decade the slowest growing of the G7 countries. The next two sections take a closer look at why this was the case.

\section{The Real Economy in the 1990s}

Actual and potential GDP growth, as well as labor-force and labor productivity growth all have slowed in each successive decade since the 1960s, as shown in Table 1.

Manufacturing led the spectacular growth of the 1950s and '60s, and continued to grow faster than the economy as a whole through the 1980s. Even though manufacturing in the 1990s grew less than the economy, labor productivity continued to increase faster in manufacturing.

Employment in the manufacturing sector grew much more rapidly than the overall labor force during the high-growth period, but beginning in the 1970s grew more slowly. In the 1990s, employment declined in manufacturing. This meant manufacturing's share of employment

increased during the rapid-growth period, going from $18.7 \%$ in 1955 to a peak of $27.1 \%$ in 1973 . 
Thereafter, its share fell slowly, standing at $24.1 \%$ in 1992 when the absolute level of manufacturing employment peaked. From 1992 to 1999 manufacturing employment declined $12.7 \%$, giving the sector a $20.8 \%$ share in 1999 . The contraction of manufacturing employment is expected to continue.

Total factor productivity growth (TFP) for manufacturing and non-manufacturing for the last 3 business cycles are given in Table 2 .

Interestingly, there has been no slackening in the pace of technological change in manufacturing. It is non-manufacturing that has exhibited much wider variations in TFP growth. In particular, there was zero technological progress for non-manufacturing in the 1990s, and it is this miserable performance that pulled down overall productivity growth in the decade. This point is important when speculating about Japan's near-term prospects.

It is generally agreed that actual growth was close to its potential until the mid 1970s, but growth since has averaged almost 1 percentage point less than the potential rate (Table 1). The question is whether the potential is now in fact even lower than the government's estimate of $3 \%$.

The potential growth rate can be decomposed into labor-force growth and labor productivity growth. Labor-force growth is further divided into the growth of the working-age population and the change in the labor-force participation rate. As Table 1 shows, beginning in the 1970s labor force growth has been slower than population growth, which means the participation rate has been declining.

It is declining labor productivity growth that accounts for most of the drop in the growth rate, and the decline is in non-manufacturing. In modern manufacturing, Japanese productivity is quite comparable to US levels. However, in the rest of the economy, especially in services, Japan lags far behind. This is because of various structural factors such as tiny retail stores, 
where low productivity is compounded by low-paid, over-worked family workers. Although large firms can compete with large US firms in international markets on more or less equal footing, small Japanese firms, especially in services, have been able to survive because they are protected from international competition.

When the actual yen-dollar rate was at $¥ 107$ in mid 2000 , the purchasing power parity (PPP) rate was about $¥ 160$. The actual exchange rate depends mostly on manufactured goods, while PPP reflects nontradeable goods and services. The large PPP gap between Japan and the United States arises because of much higher service prices in Japan, and those prices are high because productivity is low.

In international cost-of-living comparisons of major metropolitan areas in the world, Tokyo is always at or near the top of the list. Thus, in the June 2000 survey Tokyo is at 160 $($ New York $=100)$. The next most expensive city is Hong Kong, at 120.

2.1 The GDP Gap in the 1990s

Aggregate demand was weak during most of the 1990s. This is illustrated by the GDP gap, which measures the difference between real GDP (Y) and potential real GDP (Y), (Y-Y)/Y. Here I give my own estimate. The gap troughed in 1986 (during the 10th postwar recession) at $-3.3 \%$, rose through the bubble period to peak in 1990 at $4.4 \%$, and fell steadily through the Heisei (11th) recession and beyond to $-4.3 \%$ at the end of 1995 . The gap then rose to $-3.1 \%$ but then fell to $-8.3 \%$ in 1998 and $-9.9 \%$ in 1999 . (The government estimate of the GDP gap is quite similar to mine for 1990-95, but in the late 1990s quite different. The GDP gap turned 
modestly positive in1996 and turned negative in 1998 and 1999 at around $-4 \%$. This is too optimistic an estimate as I argue elsewhere.)

Demand grew sluggishly during the decade, but supply capacity maintained modest growth. Real GDP grew at an annual average of 1.9\% from 1990 to 1997, but business net fixed capital grew at $3.6 \%$ and potential GAP at $3.1 \%$.

\subsection{Private Consumption}

Private consumption is nearly $60 \%$ of GDP, so how it has behaved has had a strong impact on real GDP. There is no question that the growth of real private consumption slowed in the 1990s. It grew at $4.2 \%$ during $1986-91$, but at $1.8 \%$ in $1991-97$. In per capita terms, the rates are $3.8 \%$ and $1.5 \%$. Although this is a substantial drop, per capita growth for 1991-97 compares favorably to the EU's $0.8 \%$ rate. The US level was $2.3 \%$. Thus, considering the generally depressed state of the Japanese economy in the 1990s, consumption growth was decent by international standards. In fact, only during the recession at the end of the decade did Japanese consumers seem to have worried much about their own finances.

During the $1997-98$ recession, during which nominal GDP fell by $2.2 \%$, nominal total disposable income did not fall (it grew at $0.3 \%$ ). However, private consumption expenditures fell for the first time, at 0.4\% (nominal; 0.5\% real). Although the recession ended in April 1999, real consumption rose only by $1.2 \%$ in 1999 . Consumers apparently have become concerned about their futures. This is so because the unemployment rate continued to rise, and land prices continued to fall (land and housing are a major component of Japanese individual wealth). The 
weakness of private consumption in 1998-99 reflects the very poor state of the Japanese economy.

\subsection{Household Savings and Investment}

A structural problem in the Japanese economy is excess saving in the private sector. This is due to the high household savings rate. When growth is strong, saving is a virtue because it finances the strong demand for investment. When growth is weak, saving is a curse, as Keynes showed in the 1930s. Household savings peaked at $23 \%$ in $1974-76$, then began to fall slowly until 1990 , when it was just over $12 \%$. Thereafter, through the $1990 \mathrm{~s}$, the rate has been stable at around $13 \%$.

The fall can be attributed to two factors: the onset of slow growth and the continuing accumulation of assets. Japanese households set wealth targets and attempt to fill the gap between current savings and the target. As accumulation proceeds, the wealth gap becomes smaller, and so does the savings rate. This process was disrupted in the 1990s as households found nominal incomes growing at slower and slower rates (Table 3).

At the same time, the asset markets collapsed and showed no sign of recovery. Unemployment was rising, and life expectancies were increasing. Thus, there was growing uncertainty about a longer future, which led people to try to save as much as possible. This must be why the household savings rate remained stable through the 1990 s.

Household investment is largely in residences. As a percentage of GDP, gross residential investment has been falling (Table 3). The level is relatively large in Japan by international standards because of the higher replacement need: the economic life of Japanese homes is 
significantly less than in the United States (Japan's tax code gives 27-28 years to wooden houses' tax life. The depreciation ratio for dwellings in 1995 is, according to net stock estimates, 5.34\% (Japan), 1.55\% (U.S.), and 2.26\% (seven European countries). The tax life, estimated as 2/depreciation ratio, is 38 years (Japan), 129 years (U.S.), and 89 years (Europe). ) Reflecting migration from rural areas, there was extensive construction of housing units in urban areas during the rapid-growth period. With the coming of slow growth in the mid 1970s, the migration came to a virtual end, and overall population growth also has slowed. However, the especially low level of residential investment in the late 1990s reflected the depressed macro-economy. The proportion fell to just $4.0 \%$ in 1998 .

\subsection{Business Fixed Investment and Saving}

Business fixed investment plays a dynamic role in economic growth. On the one hand, it generates a multiplier effect in support of aggregate demand. On the other, it adds to the economy's productive capacity. Unless these two effects are well balanced, growth cannot be maintained in a smooth, steady manner, as the Harrod-Domar theory of growth clearly demonstrates. Japanese business fixed investment fluctuated significantly during the last half of the 20th century, clearly representing the macroeconomic dynamics of the times. Table 4 provides data on business fixed investment.

To appreciate the changes fully, one must look at the yearly fluctuations, which track the economy's cycles. Share peaked in 1970 at $21.0 \%$, fell to $13.7 \%$ in 1978 , stayed in the $14-15 \%$ 
range until 1984, and then rose to $19.5 \%$ in 1991 . From that peak, it fell to $14.7 \%$ in 1994 , rose to $16.2 \%$ in 1997 , and then fell to $14.0 \%$ in 1999 .

The share was still high, though falling, in the early 1970s because of the ongoing process of capital deepening. With the onset of slow growth and the cessation of capital deepening, the proportion bottomed out in 1976-84, averaging $14.9 \%$ during the period. It should be noted that during the slow-growth period, the stability in investment contributed to the stability of overall growth, especially as compared to the other G7 nations. The late 1980 s rise in share reflects the bubble economy.

Looking at growth rates gives a different picture. From 1955 to 1969, real business fixed investment grew at a tremendous rate. Despite capital deepening, the rate dropped sharply in the early 1970s, and investment barely grew in the last half of the decade? apparently reflecting a cessation of capital deepening. But deepening seems to have returned in the early 1980s, and accelerated in the late 1980 s, a side-effect of the bubble.

The business sector invests more than it saves, borrowing the difference from the rest of the economy, especially the household sector. In the rapid-growth period, this demand-supply mechanism worked well. The government maintained a balanced budget and the external sector also was nearly in balance. So, households saved and businesses invested. This ceased to be when rapid growth ended. The third column of Table 4 shows that the business sector's savingsinvestment gap. In 1998 business savings actually exceeded business fixed investment. 


\subsection{Government}

Japanese government consumption is a small part of the economy. (In what follows, the "government" is general government covering both central and local governments, and years are calendar years). Just $8 \%$ of GDP for $1960-73$ (during the rapid-growth period), it rose to $10 \%$ in 1974 and has remained around that level since. This compares to $15.4 \%$ for the United States and $18.5 \%$ for the EU-15 (1997 data). Japan's low level in part reflects defense expenditures of slightly less than $1 \%$ of GDP, while the United States spends about $4 \%$ and European countries spend $2-3 \%$. But it also reflects lower spending on health and education.

For government investment, the situation is reversed. Japan spends as much as $6 \%$ of GDP on government gross capital formation, while the other G7 nations spend 2-3\%. Japan uses government investment as an instrument of counter-cyclical policy, and its level thus varies over a cycle.

Tax revenue is far more volatile than government expenditures. (As used here, "revenue" includes taxes and net fiscal transfers.) Revenue was low and stable at around 14\% of GDP until 1973. Then the government went into deficit, mainly by cutting taxes. Revenue fell to $10 \%$ of GDP in 1978. At that point, the government began strenuous attempts to balance the budget, and revenue rose to around $17 \%$ of GDP in each of 1989, 1990 and 1991. Reflecting active fiscal policy and poor conditions in the economy, it has since declined, being 12\% of GDP in 1996 and 1997.

Until the mid 1970s, budgets ran small surpluses but, beginning in 1975, to stimulate the economy out of the recession induced by the 1973-74 oil-shock, the Diet allowed issuance of bonds to pay for deficit spending. The deficit peaked at 5.5\% of GDP in fiscal 1978. Deficit 
spending remained, but the government's goal was to eliminate it. This was achieved in 1987, and in 1990 and 1991 the surplus was $2.9 \%$ of GDP.

The Heisei recession started in February 1991, but the government was slow to reverse policy. Only in 1993 was there again a deficit (1.4\% of GDP), partly the result of tax cuts. There were further tax cuts in 1994-96, but the recovery was so anemic that the economy hardly responded to the stimulus. The deficit reached 4.2\% of GDP in 1996. Brisk growth in 1996 (a $5.1 \%$ rate) led the government to believe the economy had truly recovered, so it moved to balance the budget by lowering spending (especially government investment) and raising taxes. (The consumption tax was increased from $3 \%$ to $5 \%$ effective 1 April 1997.) The timing was quite bad, as the economy went into recession in March 1997. For 1998 the real level of government spending remained unchanged. With recession, tax revenue fell, and the government's net capital transfers expanded. Consequently, the deficit was $10.2 \%$ of GDP in 1998.

In counter-cyclical fiscal policy, timing is most important. In this regard, the Japanese government failed in the 1990s.

\subsection{Trade and Capital Flows}

The external sector plays an important stabilizing role in the Japanese economy. The trade balance has remained in surplus since the mid 1960s, except for oil-shocked 1974 and 1979-80. As a percentage of GDP it behaves counter-cyclically, falling during cyclic upswings and rising during downswings. 
The trade balance went from $-0.9 \%$ of GDP in 1980 (the first year of Japan's longest postwar recession) to $4.0 \%$ in 1986 (the first year of the next recession). Throughout the bubble years of the late 1980 s the level continued to fall, reaching $0.7 \%$ in 1990 . The Heisei recession raised it to $2.3 \%$ in 1993 , it then troughed at $0.5 \%$ in 1996 , peaked at $1.9 \%$ in 1998 , and fell to $1.6 \%$ in 1999 . This counter-cyclical property is not observed in other G7 economies: for them, the trade balance tends to fall in a recession. Why this is so is explained later.

Real exports of goods and services maintained higher and stabler growth than real GDP in the 1980s and '90s, as shown in Table 5. Note that exports were getting cheaper relative to GDP throughout the period.

An important characteristic of Japan's foreign trade is an export surplus in merchandise trade and an import surplus in (nonfactor) service trade. For example, in 1997 merchandise exports were $9.7 \%$ of GDP, imports were $7.3 \%$; service exports were $1.3 \%$, imports were $2.6 \%$. (The US pattern is the opposite: merchandise exports $7.8 \%$, imports $10.0 \%$; service exports $2.9 \%$, imports $1.9 \%$.)

Japan's merchandise exports are virtually all manufactured goods (98\%). Merchandise imports used to be primary commodities (especially petroleum in the 1970s); manufactured goods were only $20-30 \%$ of total merchandise imports. However, the share of manufactured imports started to rise rapidly in the 1980s, though the rate has slowed in the 1990s (Table 6). In 1999 it stood at $62.5 \%$, compared to the $80-90 \%$ share for other G7 countries.

The increase in manufactured imports may be related to the contraction of manufacturing within Japan. A small part of manufactured imports are the result of what is called the boomerang effect: many Japanese firms, directly or through subsidiaries, produce overseas for export into Japan. 
As a result of current-account surpluses, Japan's (net) foreign assets have continued to expand (Table 7). In the 1980s Japan became the largest net creditor to the world. According to IMF data, Japan's net foreign assets were $\$ 1,154$ billion at the end of 1998 . In contrast, the United States became a net debtor in the late 1980s and had net liabilities of $\$ 1,537$ billion. In short, Japan lends and the United States borrows.

To understand how exports, imports, and capital flows behave over time, one must look at the equilibrating role of the exchange rate. Within the context of a global fixed-rate regime that ruled until 1973, the yen-dollar rate was 360 yen per dollar from 1949 to 1971. After the August 1971 Nixon Shock, countries attempted to maintain the fixed-rate system by making a few revaluations. But, unable to maintain the old international monetary system, the world economy moved to a flexible-rate system in February 1973.

The dollar was over-valued in the early 1980s and, with the September 1985 Plaza Accord, the G5 agreed to correct this situation. Within 3 years the yen had doubled in value against the dollar. Since then, the yen-dollar rate was on a downward trend. This was because purchasing power parity (PPP) had been falling, as the inflation rate was much less in Japan than in the United States. (During 1985-99 inflation in Japan was 0.6\% annually, compared to 2.5\% in the United States.) The exchange rate fluctuations around this long-term trend have been rather unpredictable. Table 8 shows peaks and trough since the Plaza Accord.

During the Heisei recession the rate fell, and in the 1997-98 recession it rose. To understand why, one must do a little arithmetic. As noted, net exports are counter-cyclical. The reason is that imports are more responsive to the level of domestic economic activity than exports. When the economy goes into a recession, imports fall more than exports. Hence, net exports (NX) tend to expand in a recession. In addition, we may assume that NX responds 
positively to the yen-dollar exchange rate. In equilibrium, next exports and net foreign investment (NFI) are equated to one another. NFI is equal to the domestic savings surplus. When the economy goes into another recession, investment falls more than saving. As the domestic savings surplus expands, so does NFI. The yen-dollar exchange rate rises or falls, depending on whether NFI expands more or less than NX expands. During the Heisei recession, NFI increased more than NX did. The reverse was true during the 1997-98 recession.

\section{$3 \quad$ The Financial Side: The 1990s}

The real side and the financial side of an economy are two wheels of a cart, so they have to work together in harmony. When one fails, the other invariably collapses. The collapse of Wall Street in October 1929 is alleged to have led to the Great Depression of the 1930s. Likewise, the collapse of the Japanese stock market in December 1989 is alleged to have led to Japan's recessions and ultra-slow growth in the 1990s.

\subsection{Financial Deepening}

The over-expansion of the stock market in Japan in the late 1980s must be seen in the broader context of the long-term trend of financial deepening in the Japanese economy. Financial deepening is an important aspect of economic development. As an economy matures on the real side, it also becomes more sophisticated on the financial side. Innovating firms on the real side must be matched by innovating banks, securities firms, and the like on the financial side. 
Deepening means more financial activity and, hence, more financial assets relative to real production.

Let $\mathrm{F}$ be the outstanding balance of financial assets (at market prices) and $\mathrm{Y}$ be nominal GDP. Then we can take $\mathrm{F} / \mathrm{Y}$ as an indicator of financial depth. Table 9 tracks this ratio for Japan and the United States.

As the 1990s ended, Japan and the United States had comparable levels of financial depth, but there is a wide difference as regards financial structure, particularly the relative position of money. Here we must look at money and its counterpart, bank loans, both of which are part of F. In 1998 for Japan, money (M3 plus CDs, thus including currency, bank deposits, and postal savings) was $26.1 \%$, and loans (by private and public financial institutions) were $24.8 \%$ of total F. For the United States, the shares were $6.2 \%$ and $11.0 \%$. (US loan data include bank loans, other loans, and mortgages.) Thus, banks account for half of outstanding financial assets in Japan, but only one-sixth in the United States.

Money plays a prominent position in Japanese finance because households hold most of their financial savings in the form of money. In 1998, 64.5\% of household sector F was money. Money was followed in importance by life insurance equity (24.3\%). Japanese families love life insurance far more than those in other countries (in Japan, life insurances are a form of long-term saving. If the subscriber survives until the maturity date, he/she is paid the accumulated sum in full). Japanese households own few stocks and bonds: corporate stock was just $6.3 \%$ of F. For US households, money was $12.0 \%$, and life insurance equity a mere $2.3 \%$, while stock was $16.3 \%$ of their total $\mathrm{F}$ in 1998 . Moreover, because $29.1 \%$ of US household $\mathrm{F}$ was in pension funds, and corporate equities were $27 \%$ of pension-fund reserves, US households exposure to equities rises to almost $25 \%$. 
In the United Sates, the stock-market's spectacular rise in the 1990s is alleged to have exerted a wealth effect on private consumption. In Japan, because households own few corporate equities, private consumption may have been insulated from any wealth effect (which would have been primarily negative in Japan's case, given the course of the market in the 1990s). The wealth effect from sinking land prices is a different story. Despite exorbitantly high land prices, home ownership is high in Japan at 60\% in 1998, which is comparable to the US level of $64 \%$. Thus, land is a particularly important asset to Japanese households, accounting for $40 \%$ of total household assets; dwellings add another 10\%. Those who bought during the bubble period have suffered much from falling prices. Because home purchases typically depend on mortgages that may exceed current values, personal bankruptcies have mushroomed since the late 1990s.

Japanese households are inclined to hold money and life-insurance products because of strong risk aversion. However, households diversified away from money during the 1980s, as shown by the sharp rise in life insurance equity as a financial asset (Table 10). They also shifted to (potentially) more profitable assets such as stocks during the late 1980s bubble as the earnings motive overrode the security motive. But with the collapse of the bubble in 1989 , there was a shift back to money although insurance continued to increase share during the 1990s. This reflects a reassertion of the security motive.

When households save and increase their bank deposits, postal savings, and life insurance equity, financial institutions as their depositories must lend the funds out. The loan balance in the economy expanded at an average rate of 9.3\% from 1980 to 1990, while nominal GDP grew at $6.0 \%$. In the $1990 \mathrm{~s}$ (to 1998), however, loan balances grew only modestly, at $2.6 \%$, while nominal GDP grew just 1.9\%. The ratio of loan balances to GDP moved from 1.51 (1980), to 2.06 (1990), to 2.16 (1998). 
Apart from money and life insurance, the outstanding balance of government bonds continued to increase as government deficits persisted. As a percentage of the economy's total F, the balance of government bonds (national, local, and public corporations) rose from $4.4 \%$ (1974) to $9.9 \%$ (1998). One must note that $96 \%$ of these bonds are held by financial institutions and government agencies.

\subsection{The Fragility of the Banking System}

When households save in bank deposits and postal savings, banks (private and public) must lend the funds, mainly to business firms. Hence, bank loans and bank deposits change more or less equally in volume. For deposit-taking banks, the loan balance was $92.2 \%$ of the deposit balance as of the end of 1998 .

An important economic point here is how fast bank loans expanded, and who borrowed the funds. As noted, the loan balance out-stripped nominal GDP in growth through the 1980s. For domestically licensed banks (zenkoku ginko, which are the deposit-taking banks other than shinkin), from 1980 to 1990 the lending balance grew at an average rate of $6.5 \%$. According to the banks, their lending to small firms expanded at an annual rate of $14.4 \%$, while loans to individuals increased at $14.9 \%$, and loans to all others grew at $4.6 \%$. The result of these differences in growth rates are reflected in Table 11, which shows the distribution of loans by type of borrower.

Because (as groups) small firms and individuals are more risky than large firms as borrowers, the banks' credit risk increased steadily through the 1980s. This is clearly the other 
side of financial deepening. However the monetary authorities kept silent on this increase in the systemic risk that was creeping steadily through the system.

Unlike in the 1980s, the deposit balance and the loan balance diverged from one another in the 1990s. From 1990 to 1999, the deposit balance of the deposit money banks grew at an average annual rate of $2.4 \%$ and the loan balance at $0.7 \%$ (from 1980 to $1990,9.3 \%$ and $9.6 \%$ respectively. Nominal GDP grew at 6.0\% (1980-90) and 1.6\% (1990-99) respectively). Small firms' share of the loan balance rose in the 1980s, but in the 1990s it remained stagnant and, in fact, contracted in the late 1990s as lenders became weary of high-risk borrowers. This is the kashi-shiburi phenomenon (reluctance to lend) that was much talked about during the 1997-98 recession.

Through the 1980s, especially the late '80s, monetary policy remained relaxed, allowing the money supply and credit supply to grow at a fairly rapid rate. The Bank of Japan continued to cut the discount rate, and bank lending rates and other market interest rates followed. This generous monetary policy gave rise to the economic bubble of the late 1980s. But the seed for future troubles was planted at this time, as banks had to accept more and more credit risk to put their funds to work.

Risky borrowers included real-estate speculators. They became notorious in the late 1980s for the aggressive tactics (jiageshi) used to force owners to sell and tenants to move so that they could assemble sites for redevelopment. The speculators financed their activities primarily with loans from jusen (housing loan companies). These had been set up as nonbank subsidiaries by the large city banks and agricultural cooperatives in the 1970s. Jusen did not accept deposits, instead funding themselves by borrowing from their parent banks and co-ops. As nonbanks, they were not subject to government banking regulations. Indeed, they were basically unregulated. 
Many of their loans went to borrowers who were considered too risky by their parents. Loan balances at jusen grew at an annual average of 15\% from 1980 to 1990.

Such loans were not a problem as long as the bubble continued, and large profits were made as real estate values climbed. Unfortunately, the land-market bubble ended around 1990. Speculators were stuck with undevelopable land. Unable to pay even the interest on their loans, they defaulted. The epidemic of bad loans was given the official euphemism "nonperforming loans".

When a lending institution is burdened by too many bad loans, it has to declare itself bankrupt. The first to go were the 7 jusen. The parent banks and co-ops refused to take responsibility for their subsidiaries' failure. In 1996 the Ministry of Finance decided to allow the jusen to liquidate, with their nonperforming loans taken over by the government.

Initially, banks hid bad loans. Loans in default were given extended maturities, lower interest rates, and even loans to pay interest due. This was done in the belief that, with time, the economy would recover and the loans could be repaid. But that did not happen, and by the mid 1990s the bad loan problem could no longer be covered up.

The convoy system was for a long time the basic principle of Japan's monetary administration. The authorities extended assistance to the weakest banks to enable them to survive, the stronger banks were expected to take care of themselves. In this way, there were no bank failures during the slow-growth period. In the 1990s, MOF abandoned the convoy system, and let the survival of the fittest be a new guiding principle. As a result, the government allowed a few small banks to go bankrupt.

However, some of the larger banks were showing signs of serious trouble. Among them was Hokkaido Takushoku Bank, one of the smaller of the 12 city banks. It went bankrupt in 
November 1997. Yamaichi Securities, one of the big-four brokerage houses, went bankrupt the same month. Nissan Life Insurance, a mid-size firm, failed around the same time. MOF responded by seeking to reactivate the convoy system. In October 1998 the government nationalized the Long-Term Credit Bank of Japan (LTCB) rather than allow it to declare bankruptcy. Reorganized and with a restructured balance sheet, it subsequently was reprivatized.

Even when nonperforming loans could no longer be hidden entirely, MOF and the banks continued to down-play the problem. The first estimates published in late 1995 by MOF put nonperforming loans at $15 \%$ of total loans. Banks were instructed to write them off according to a schedule. Unfortunately, as old bad loans are taken care of, new ones have cropped up. Hence, the liquidation has become a long, drawn-out process. While banks suffer from nonperforming loans, they cannot be strong.

In the meantime, after being tightened in 1989-90, monetary policy was relaxed. The Bank of Japan (BOJ) cut the discount rate repeatedly, eventually, in September 1995, to 0.5\%, the lowest level in Japan's history. Since then, the rate has remained unchanged. For a practical policy instrument, BOJ intervenes in the call market. (The call or interbank market in Japan is comparable to the federal-fund market in the United States, with banks extending or taking out very short-term call loans.) As a result, the call rate for non-collateralized overnight loans, which had been higher than the discount rate, dropped below the discount rate in September 1995 and, in August 1998, it fell toward 0. In October 1999 it was 0.02\%. In other words, call loans became virtually free. This was dubbed the "zero-rate" policy. Still, the economy refused to be reinvigorated. In August 2000, BOJ judged the economy had gained enough momentum to end 
the zero-rate policy, and raised the target call rate to $0.25 \%$. The Ministry of Finance argued this was premature.

In April 1998 a revised Bank of Japan law took effect, giving BOJ some independence from the government in general and the Ministry of Finance (MOF) in particular. This included reorganizing the bank's decision-making body, the Policy Board. The August 2000 policy change marked the first instance of BOJ standing against pressure from MOF. Until then, in the field of monetary policy, BOJ always obeyed instructions from MOF. Whether BOJ can make itself as independent as the US Federal Reserve or the Germany's Bundesbank is yet to be seen.

\subsection{Business Groups}

The predominance of large business groups (commonly termed keiretsu) is a well-established feature of the Japanese economy. The six largest -- Mitsui, Mitsubishi, Sumitomo, Fuyo, Sanwa, and Dai-ichi Kangin -- average 4 financial institutions and 26 non-financial corporations, 20 of which are in manufacturing, especially heavy industry. The financial institutions are a city bank, a trust bank, a non-life (fire and marine) insurance company, and a life insurance company. The city bank and life insurance company are of particular importance because they extend loans to the group's non-financial firms, with the bank serving as the members' "main bank". The Fuyo group is centered on Fuji Bank, and Dai-ichi Kangin on Dai-ichi Kangyo Bank. Otherwise, at one time the bank names were eponymous with the groups but, as result of mergers, the Mitsui group bank is called Sakura and the Mitsubishi group bank is Bank of Tokyo-Mitsubishi.

Until 1945 the groups were controlled by zaibatsu families through a holding company, with the banks and other financial institutions being of less importance. The groups engaged in 
capital-intensive and technology-intensive industries. The US government felt the zaibatsu families were responsible for Japan's aggression, so after World War II the families were required to sell their equities. The holding companies were dissolved, and shares in the various firms dispersed relatively widely.

However the firms soon began to regroup, creating enterprise groups (kigyo shudan), which later came to be called keiretsu. With no centrifugal zaibatsu family and holding company, a group is a cooperative organization of firms. However, the city bank and the life insurance company are considered the core of the group.

The groups initially primarily were in manufacturing and trade but, as time went on, finance increased in importance. This is seen in the distribution of assets between financial and non-financial firms within the groups (Table 12). This indicates how the 6 groups have taken advantage of the economy's move toward financialization.

The increasing financialization of the 6 groups also is seen in the fact their share of sales in the non-financial corporate sector stayed at $15 \%$ or so from 1970 to 1990 , but fell to $12 \%$ in the late 1990s. By contrast, looking just at banks and insurance companies, the groups' share of total assets rose from $42 \%$ in 1970 , to $51 \%$ in 1980 , to $58 \%$ in 1990 . In the 1990 s the share has fallen somewhat and been volatile.

All this means that by the 1990 s the 6 groups had transformed themselves from production groups into financial groups. With the poor performance of the financial sector in the 1990s, the large business groups have accordingly also done poorly.

This poor performance has prompted some action in the form of mergers. In early 2000 all 6 groups announced either mergers involving their main banks or the forming of holding companies that brought their financial institutions together. This reduces the 6 major groups to 4 
as regards banks (Table 13). (After World War II holding companies had been banned as part of the zaibatsu dissolution. A 1997 revision to the law allows them subject to certain restrictions.) The existence of a main bank has been the hallmark of a business group. When these banks merge or join hands, the raison-d'etre of the group itself must be questioned. How this change affects groups is yet to be observed.

The Japanese Economy: Quo Vadis?

After a decade of stagnation and ultra-slow growth, where will the economy go in the 21 st century?

The government issues a national economic plan every 5 years or so, among other things setting a growth target. Table 14 gives the projected and actual growth rates for plans since 1988. The $3.0-3.5 \%$ growth target for the 1990 s corresponds to the potential growth rate of $3 \%$ which was generally believed to apply to this decade. But the actual fell far short of the potential. Having miserably failed in the two 1990s plans, the government apparently has lowered its sights for the first decade of the new century.

With population growth of $0.3 \%$ in the $1990 \mathrm{~s}, 3 \%$ target GDP growth implies $2.7 \%$ per capita growth. In 1999-2010, total population will be virtually stationary (assuming the lower end of the population projections), so per capita growth and target overall growth would be the same 2\%. Apparently the government has become much more pessimistic about growth prospects. But cannot Japan achieve at least $2.7 \%$ per capita growth in the coming decade? 
To answer this question, I conduct a simple exercise involving labor productivity (LF) growth. Also, following the new OECD classification, the economy is divided into industry (mining, construction, manufacturing, and electricity) and nonindustry.

First, using the first years of recessions to establish the periods, we compare 1985-91 and 1991-97. LP growth fell from $3.3 \%$ to $1.0 \%$ in the total economy, from $3.5 \%$ to $2.7 \%$ in industry, and from $3.2 \%$ to $0.5 \%$ in nonindustry. The decline in LP growth was $67 \%$ in the total economy, which is the weighted average of $23 \%$ in industry and $84 \%$ in nonindustry. As noted earlier, total factor productivity (TFP) growth gives an even more striking contrast been industry and nonindustry. Industry, particularly manufacturing, held its own in the 1990s. The problem is with nonindustry.

To see whether Japan's experience is unusual, compare it to 1990-98 LP growth in the other G7 nations. For the total economy, LP growth ranged between 1.2\% (Canada) and 2.3\% (Germany), with a simple average of $1.7 \%$. Japan's $1.0 \%$ is by far the worst of the group. To achieve even the average would be a significant improvement.

For industry, LP growth ranged from 2.6\% (Italy) to 5.4\% (United States), with a simple average of $3.8 \%$. Japan's $2.7 \%$ is again at the lower end of the range. If the United States can achieve $5.4 \%$ in an economy larger than Japan's, surely Japan can do better than it has.

For nonindustry, LP growth ranged from $0.6 \%$ (Canada) to $1.8 \%$ (United Kingdom), with a simple average of $1.2 \%$. Once more Japan is at the bottom, with a mere $0.5 \%$. Although it generally is difficult to improve productivity in nonindustry, in the Japanese case, there are many areas, especially in the service sector where, Japan's productivity levels lag far behind other advanced countries. The present hope is the information technology revolution (IT), on which 
much has been written. All this suggests it must be possible to set the target growth at a higher level.

In the 1980s Japan's LP growth rate in nonindustry was as high as 3.2\%. If LP growth can be raised to its 1980 s level, Japan's potential growth can be $3 \%$ or higher. One must, however, keep in mind two negative factors: the rapid decline in the working-age population and the absolute decline in manufacturing.

\subsection{Population and Labor Force Growth}

The steady decline in the size of the labor force (and projected decline in total population) is a serious hurdle to increased growth. The Ministry of Health and Welfare in 1997 projected that, at the low end of the estimates, total population would peak at about 127 million around 2004 and by 2050 have fallen $27 \%$ to 92 million.

The total fertility rate (TFR, the number of children the average woman has in her lifetime) was just 1.38 in 1999 , well below replacement level, which is slightly above 2 . The decline in TFR reflects a number of factors. Marriage occurs later. Once, 25 was considered the upper limit on a woman's being marriageable; after that, she was considered an old maid and society looked askance at her. This is no longer the case. Indeed, many women choose not to marry at all. Later marriage means fewer children, at least in Japan, where children born out of wedlock have remained at around 1\% since the 1960s. (This is in sharp contrast to other advanced countries: from 1960 to 1996 the share of live births to unmarried women rose from $11 \%$ to $53 \%$ in Sweden (which has the highest level), and even in Catholic Italy it went from $2.4 \%$ to $8 \%$. In the United States, it went from $5 \%$ to $32 \%$.) Social sanctions against illegitimate 
births remain powerful in Japan. This means total fertility will remain low, and fall further, if women become even more independence-minded and prefer singlehood to motherhood.

The population is getting older. This is a universal trend in developed countries, but the process has been remarkably rapid in Japan. The share of the population 65 or over has risen from $5 \%$ in 1950 to $17 \%$ in 2000 , and is expected to reach $32 \%$ in 2050 . Many older men have preferred to continue working (their labor-force participation rate has hovered around 37-38\% since the mid 1980s), so the labor force may not decline as much. However, fewer children and more oldsters means a continued rise in the average age of a worker. Older workers generally are considered less capable or willing to learn new tricks and be otherwise less amenable to change, although this is partly offset by maturity and the proficiency that comes with experience.

The decline in the labor force can be supplemented by importing foreign workers (as the United States does). But xenophobia remains very strong in Japan. Despite an influx of illegal aliens in the late 1980s and early '90s, the number of aliens residing in Japan is still less than 1\% of the population. (This excludes Koreans born in Japan, who are treated as aliens.) Unless there is a fundamental change in the Japanese psyche, the labor supply is not likely to be supplement by in-migration.

One more point about aging is its social and economic costs. The social security system is expected to go bankrupt soon if the present contribution-benefit system continues. Medicare, introduced in the 1980s, will become too much of a burden on public finance. In April 2000, a new geriatric care insurance (kaigo hoken) went into effect under government administration to give medical treatment to the seriously invalid old. In earlier times, the family was expected to take care of its aging grandparents, but the 3-generation family has been on the decline, and the 
younger generation is less willing to care for aging parents. In this regard, Japan's society is clearly in a transition.

\subsection{The Service Revolution, Industrial Structure, and the Trade Balance}

Manufacturing was the engine of Japan's rapid growth. Even though its importance diminished in the slow-growth period, its share of employment did not fall until 1992. This is quite different from the other G7s, where manufacturing employment was falling in share, and even absolute number, once the service revolution started. Since 1992, manufacturing employment in Japan has declined $14 \%$ in absolute number, and the contraction is expected to continue.

Employment in trade was stationary in the 1990s, so most of the decade's increase in the labor force was in services. This change in employment structure reflects a change in demand structure, which is related to, among other things, the aging of the population. Although younger households spend significantly on industrial goods, households after middle age apportion their consumption expenditures more toward services such as leisure activities. Moreover, the older segments require more medical care.

As the demand for goods falls relative to total GDP, manufacturing contracts. GDP originating in manufacturing was nearly flat in the 1980s as a percentage of total GDP: $29 \%$ in $1980,28 \%$ in 1990 . However, in the 1990 s the share started to decline; it was $24 \%$ in 1998. Manufacturing exports followed a quite different course, going from $43 \%$ of GDP in manufacturing in the early 1980 s to $33 \%$ in the early 1990 s, but had risen back to $43 \%$ in 1998 . It should also be noted that industrial goods are supplied increasingly by imports. 
The US experience is encouraging. There, manufactured exports rose from a low of $21 \%$ of GDP in manufacturing around 1985 to $43 \%$ in 1997 . This seems to indicate that even though domestic manufacturing may contract, manufactured exports may not.

Whether net exports rise or fall as a percentage of GDP depends on how the domestic savings-investment balance behaves. This is because, in equilibrium, net exports and net foreign investment are equal. Let us assume that the government eventually succeeds in balancing its budget. Then the savings-investment balance in question is that of the private domestic sector. If the growth rate is to be, say, $2 \%$ as the government's economic plan projects, it is inevitable that domestic private investment will fall as a share of GDP.

Will the household savings rate fall below the $13 \%$ level of the 1990s? The answer to this question is unclear. On the one hand, the ongoing population aging may force households, especially old ones, to consume more and save less (logical if providing for old age is a reason for saving). But, so far, that has not happened. It is known that Japan's household saving exhibits the following pattern. When young, the savings rate is relatively high. For the older and retired, incomes from public and private pensions tend to fall toward subsistence, so there is no saving, and even dissaving. However, a large percentage of older males continue to work. As a result, they have more income than they currently need, and thus tend to save even more than younger households. With increased life expectancies, all households may try to save as much as possible for an uncertain future. If so, the household savings rate may not fall as much, and the private savings surplus may persist. 


\subsection{Work Ethic}

In the final analysis, the strength of a national economy lies in the vitality of its labor. Japan's celebrated "lifetime" employment system, with its mutual commitment, allowed both firms and workers to evolve to meet changing needs and markets as the economy grew. In the 1990s, however, the system started to show signs of breaking down. This trend was accelerated by the rise of the unemployment rate from $2 \%$ toward $5 \%$. When employment is no longer secure, employees are discouraged from acquiring the traditional characteristics of Japanese labor. High mobility may be a sign of labor-market mobilization, but the economy may have to pay a high price for it.

Labor of high quality is produced by a well-functioning education system. Although the "exam hell" is criticized for killing student initiative in original thinking, Japan used to take pride in its schools. Unfortunately, the system has started to show serious signs of unravelling, especially at the junior-high school level. Ijime (harassment or tormenting) started to rise sharply in these grades in the mid 1990s. Bullies torment classmates who are mentally or physically weak. In extreme cases, this has led to suicides. School authorities invariably claim they are unaware of ijime in their schools, apparently seeking to excuse themselves of any responsibility for the violence.

A related phenomenon is a sharp increase in those students who refuse to go to school. According to an August 2000 Ministry of Education report, junior-high students who cut classes more than 30 days in a school year were $2.5 \%$ of the student population in 1999 . Over the 8 years since the surveys were started, delinquents have doubled in number. 
In addition, in 1999, 22.5\% of new college graduates were unemployed. Although some were jobless because of the depressed labor market, others were so by choice. There also are large numbers of young people who have closeted themselves at home, shutting themselves off from society.

These and other events indicate that Japanese society started to be ailing in the 1990s. Something has gone fundamentally amiss and, if not remedied, it, more than anything else, may undermine the foundation of society.

\subsection{The Economic System}

Japan has, since the early 1950 s, been ruled by the triad of elite bureaucracy, political parties, and big business. The general populace benefited from postwar economic growth sufficiently to have little concern for the give-and-take among the elite groups. But now, more often than not, the triad's collaboration has degenerated into collusion and corruption. Since the mid 1980s there have been recurrent scandals involving members of the triad, and the scandals became more numerous in the late 1990s. This is reflected in the international corruption index. Japan is exactly in the middle of the list, which means it ranks low among developed countries.

As a general rule, the more regulated an economy, the more often there is corruption. Thus, Indonesia and China are considered quite corrupt. On the other hand, Singapore is on the top of the index, reflecting strict enforcement of its laws and the severe punishment meted out to those who violate them.

Japan intensified regulations during World War II and kept them largely unchanged after the war (the so-called 1940 system). This meant the elite bureaucracy became quite powerful. 
National politics was run largely by the Liberal Democratic Party (LDP), which was in power continuously for 38 years after its formation in November 1955. It lost its Diet majority in July 1993, but after 9 months returned to the government. Needless to say, politicians in power have a great deal to give. In return, they take from big businesses in the form of political contributions.

The give-and-take system is still in operation. Deregulation became a popular issue in the 1990s, and the government is supposed to push ahead. In reality, members of the triad have been dragging their feet, stalling deregulation to protect their own interests. The elite bureaucracy, butt of much public criticism for its poor handling of various crises of the 1990s, remains powerful. The LDP again lost a majority in the Diet (House of Representatives) in the June 2000 elections, but with 233 seats (out of 480) it remains in power.

It seems the triad will run Japan for the time being.

\section{Conclusion}

Japan is the first country that achieved the economic miracle of rapid growth. From its stellar performance in the 1960s, it moved into a slow-growth period (1975-90) during which it still maintained the highest growth, and lowest inflation, among the G7 economies. However, in the 1990s it had the lowest growth rate among the G7. This stagnation is due to three major factors. One is the short-term reaction to the over-expansion of the economy in the late 1980s, especially on the financial side. The financial sector still is struggling with the aftermath of the bubble -indeed, the situation deteriorated further in the late 1990s. The second factor is the on-going 
decline of manufacturing. Manufacturing drove Japan's growth, especially its productivity growth, but now employment is falling in that sector. The third factor is long-term changes in the population structure, specifically, the rapid aging of the population and the low level of the birth rate. Manufacturing drove Japan's growth, especially its productivity growth, but now employment is falling in that sector. All these changes have serious macroeconomic effects on the economy.

The 1990s probably is a turning point as momentous for Japan as the Meiji Restoration and the defeat in World War II. On those occasions, Japan's economic system was significantly transformed. Modern economic growth followed the Meiji Restoration, and the economic miracle of rapid growth followed World War II. If the Japanese economy is to be revitalized, an equally intensive and extensive overhaul is required, urgently. But, unlike the preceding turning points, this one has to be undertaken with no coercion from the outside. If Japan does not succeed at this task, its future will be dismal. This is really a critical moment for the Japanese economy. 
Table 1. Overview, by Growth Periods, 1960-97

(Annual growth, in percents)

\begin{tabular}{|c|c|c|c|c|c|}
\hline Rapid $^{1}$ & Transition & Slow & \multicolumn{2}{|c|}{ Ultra-slow ${ }^{2}$} & Growth period \\
\hline 1960 & 1970 & 1975 & 1991 & 1991 & Years \\
\hline-69 & -74 & -90 & -97 & -99 & \\
\hline 10.5 & 5.9 & 4.1 & 2.0 & 1.3 & Actual GDP \\
\hline$>10$ & - & 5 & 3 & - & Potential GDP \\
\hline 1.9 & 1.1 & 1.2 & - & 0.8 & Population 15 or older \\
\hline 1.9 & 0.9 & 0.9 & 0.8 & 0.7 & Labor force \\
\hline 8.4 & - & 3.2 & 1.2 & 0.6 & Labor productivity \\
\hline 14.8 & 8.1 & 4.4 & 2.0 & 0.9 & $\begin{array}{l}\text { Manufacturing: } \\
\text { Real GDP }\end{array}$ \\
\hline 4.3 & 0.0 & 0.4 & -0.5 & -1.1 & Employment \\
\hline 10.1 & - & 4.0 & 2.5 & 2.0 & Labor productivity \\
\hline
\end{tabular}

1 Most discussion take the first oil shock (1973-74) as the end of the rapid-growth period. Here, data are given separately for the 1960 s to show the economy's dynamism during that decade.

2 The 1991-99 rates are lower than those for 1991-97 because the economy shrank in 1998. 
Table 2. Total Factor Productivity Growth, 1979-97

(Annual percentage rates of growth)

$\begin{array}{cccl}1979-85 & 1985-91 & 1991-97 & \\ 2.6 & 2.7 & 3.0 & \text { Manufacturing } \\ 1.2 & 1.8 & 0.0 & \text { Non-manufacturing }\end{array}$

Data are for business cycles measured from the first year of a recession.

Total factor productivity growth is the residual after subtracting the weighted average of labor input growth and capital input growth from total output growth. It represents technological change. Capital input is represented by the official estimate of the gross fixed capital stock. As it considerably overstates capital growth, TFP growth is understated. But the direction of change remains the same. 
Table 3. Household Incomes, Saving, and Investment, 1975-98

$\begin{array}{rrrrrl}\text { (In percents) } & & & & & \\ & & & & & \\ 1975 & 1980 & 1985 & 1990 & 1995 & \\ -79 & -84 & -89 & -94 & -98 & \\ 10.9 & 5.9 & 4.7 & 4.4 & 1.5 & \text { Income growth }^{1} \\ & & & & & \\ 10.0 & 9.1 & 8.3 & 6.8 & 7.0 & \begin{array}{l}\text { Household, as percent of GDP: } \\ \text { Saving }\end{array} \\ 7.0 & 5.5 & 5.3 & 5.3 & 4.7 & \text { Gross residential investment }^{3}\end{array}$

Average annual increase in nominal household income.

2 Net saving (saving minus investment) by the household sector during the period.

3 In 1970-74, gross residential investment by households was $7.1 \%$. 
Table 4. Business Fixed Investment, 1955-90

$\begin{array}{rrrr}\begin{array}{c}\text { As } \% \\ \text { of GDP }\end{array} & \begin{array}{c}\text { Real } \\ \text { Growth }\end{array} & \begin{array}{c}\text { Savings } \\ \text { Gap }^{2}\end{array} & \\ 13.3 & 21.1 & - & 1955-59 \\ 18.9 & 19.1 & - & 1960-64 \\ 17.7 & 16.5 & - & 1965-69 \\ 18.9 & 5.4 & -7.5 & 1970-74 \\ 14.8 & 2.0 & -5.8 & 1975-79 \\ 15.7 & 5.2 & -4.9 & 1980-84 \\ 16.7 & 10.7 & -5.6 & 1985-89 \\ 17.8 & { }^{\mathrm{a}}-1.1 & -5.4 & 1990-94 \\ 15.1 & { }^{\mathrm{b}} 2.1 & { }^{\mathrm{c}}-0.1 & 1995-99\end{array}$

1 Annual rate from the beginning to end of the period.

2 Business saving minus business fixed investment, as a percentage of GDP. The business saving series is not carried backward beyond 1970 in the revised national accounts.

a The growth rate is somewhat misleading as investment peaked in 1992 and troughed in 1994.

b The growth rate is somewhat misleading as investment peaked in 1997 and troughed in 1998-99.

c Data are for 1995-98. In 1998 business saving exceeded business investment. 
Table 5. Growth of Exports and GDP, 1978-98

(Annual percentage rates)

$\begin{array}{cccl}1978-86 & 1986-93 & 1993-98 & \\ & & & \\ 6.5 & 4.7 & 5.0 & \text { Real exports } \\ 3.5 & 3.6 & 1.2 & \text { Real GDP } \\ -2.9 & -1.1 & -5.0 & \text { Relative prices }\end{array}$

Rates are measured from peak-to-peak of the trade balance's share of GDP.

1 Growth of export price deflator minus growth of GDP price deflator. 
Table 6. Manufactured Goods as a Percentage of Total Imports

$\begin{array}{lrrrr}1980 & 1985 & 1990 & 1995 & 1999 \\ 21.3 & 31.5 & 49.8 & 59.9 & 62.5\end{array}$


Table 7. Japanese Net Foreign Assets as a Percentage of GDP

$\begin{array}{rrrrr}1970 & 1980 & 1990 & 1998 & 1999 \\ 2.3 & 1.2 & 11.4 & 26.7 & 17.1^{\mathrm{a}}\end{array}$

Assets are valued in current prices.

a The decline in 1999 is due partly to a sharp rise in the value of the yen. 
Table 8. Yen-Dollar Exchange Rate, Peaks and Troughs, 1985-2000

$\begin{array}{rrrrrr}\text { Feb } & \text { Apr } & \text { Apr } & \text { Apr } & \text { Aug } & \text { June } \\ 1985 & 1988 & 1990 & 1995 & 1998 & 2000 \\ & & & & & \\ 260 & 125 & 158 & 84 & 145 & 105\end{array}$


Table 9. Ratio of Financial Assets to Nominal GDP (Financial Depth) in Japan and the United States.

$\begin{array}{rrrrrrl}1955 & 1970 & 1985 & 1989 & 1992 & 1998 & \\ & & & & & & \\ 2.3 & 4.0 & 6.7 & { }^{\mathrm{a}} 9.4 & 7.9 & 8.7 & \text { Japan } \\ . . & 4.5 & 5.7 & { }^{\mathrm{b}} 6.3 & . . & 8.7 & \text { United States }\end{array}$

Data are for calendar year-end.

a Peak.

b 1990 . 
Table 10. Distribution of Japanese Household Financial Assets

$\begin{array}{rrrrrrrl}1970 & 1975 & 1980 & 1985 & 1990 & 1995 & 1998 & \\ & & & & & & & \\ 65.3 & 68.1 & 66.9 & 62.7 & { }^{a} 50.3 & 60.7 & 64.5 & \text { Money }^{1} \\ 11.2 & 10.8 & 11.7 & 14.4 & 18.3 & 22.6 & 24.3 & \text { Insurance equity }^{2}\end{array}$

1 M3 plus CD, which includes currency, bank deposits, and postal savings.

a 1989 , representing the height of the bubble. 
Table 11. Distribution of Bank Loans by Type of Borrower

\begin{tabular}{lccc} 
Small firms & \multicolumn{2}{c}{ Individuals } & All Others \\
41.4 & 1980 & 11.2 & 47.5 \\
57.1 & 1990 & 16.2 & 26.7
\end{tabular}

Banks are deposit-taking banks except shinkin. 


\section{Table 12. Share of Assets Held by Financial Firms}

$\begin{array}{lrrrl}1970 & 1980 & 1990 & 1995 & \\ 53 & 64 & 77 & 77 & \text { Major keiretsu }^{1} \\ 33 & 42 & 48 & 52 & \text { All }^{2}\end{array}$

1 Share of the assets of the financial firms in the six major keiretsu as a percentage of the assets hald by all firms in the keiretsu.

2 Share of the assets of all financial firms as a percentage of the assets hald by the entire corporate sector. 
Table 13. Major Financial Groups in 2001

\author{
Mizuho Financial Group ${ }^{1}$ \\ Dai-ichi Kangyo Bank \\ Fuji Bank \\ Industrial Bank of Japan (IBJ) \\ (Yasuda Trust \& Banking Co Ltd) \\ Mitsubishi Tokyo Financial Group ${ }^{2}$ \\ Bank of Tokyo-Mitsubishi \\ Mitsubishi Trust \& Banking Corp \\ Nippon Trust Bank Ltd \\ Sumitomo Mitsui Banking Corp ${ }^{3}$ \\ Sumitomo Bank \\ Sakura Bank \\ UFJ Group ${ }^{4}$ \\ Sanwa Bank \\ Tokai Bank \\ Toyo Trust \& Banking Co
}

The seven largest city banks have formed into four major groups, which are listed here with their principal components as announced through October 2000.

1 The three banks are merging. Yasuda Trust is a subsidiary of Fuji Bank. Various affiliates of the banks also are merging, forming Mizuho Securities Co and Mizuho Trust \& Banking Co. All are under Mizuho Holdings Inc. Mizuho means "fresh and fruitful harvest of rice". With March 2000 assets of $\$ 1,276$ billion, the Group would have been the largest financial institution in the world.

2 Nippon Trust has been a majority-owned subsidiary of BTM since 1997. With March 2000 assets of $\$ 1,154$ billion, the Group would have been the second largest financial institution in the world. Bank of Tokyo-Mitsubishi was formed by merger in 1996.

3 The two banks are merging. With March 2000 assets of $\$ 927$ billion, the Group would have been the third largest financial institution in the world. Sakura Bank is the result of the 1990 merger of Mitsui Bank and Taiyo Kobe Bank.

4 Sanwa and Tokai are merging in April 2002. UFJ stands for United Financial of Japan. The umbrella company is UFJ Holdings Inc. With March 2000 assets of $\$ 666$ billion, the Group would have been the fifth largest financial institution in the world.

Source: Takeo Hoshi and Anil Kashyap, Corporate Financing and Governance in Japan, Table 9.4. (The MIT Press, 2001).

Asset data and ranks as reported in the Nikkei Weekly (25 Sep 2000, p 23). 
Table 14. Growth Targets of National Economic Plans, 1988-2000

(Annual growth in per cent)

$\begin{array}{lccl}\begin{array}{c}\text { Plan } \\ \text { years }\end{array} & \begin{array}{c}\text { Target } \\ \text { growth }\end{array} & \begin{array}{c}\text { Actual } \\ \text { growth }\end{array} & \text { Plan name } \\ 1988-92 & 3.75 & 4.0 & \text { Living With the World } \\ 1992-96 & 3.5 & 0.5 & \text { Quality of Life } \\ 1996-2000 & 3.0 & 1.2^{\text {a }} & \text { Structural Reform } \\ 1999-2010 & 2.0 & . . & \text { Economic Revival }\end{array}$

a 1995-99. 


\section{CENTER ON JAPANESE ECONOMY AND BUSINESS Working and Occasional Papers}

(copies can be downloaded free of charge at: $w w w . g s b . c o l u m b i a . e d u / j a p a n)$

Last update: September 1, 2005

\section{WORKING PAPERS}

241 Robert A. Myers, Challenges for Japanese Universities' Technology Licensing OfficesWhat Technology Transfer in the United States Can Tell Us

240 Takatoshi Ito, Political Economy of Competition Policy in Japan: Case of Airline Services

239 Christina L. Ahmadjian, Stability and Change in Embedded Relationships: Broken Ties in Japanese Automotive Keiretsu

238 Nada Mora, The Effect of Bank Credit on Asset Prices: Evidence from the Japanese Real Estate Boom during the 1980 s

237 Koichi Hamada and Asahi Noguchi, The Role of Preconceived Ideas in Macroeconomic Policy: Japan's Experiences in the Two Deflationary Periods

236 Takatoshi Ito, Monetary Policy Beyond the Zero Interest Rate Policy Under Deflation

235 Hiroyuki Chuma, Takao Kato and Isao Ohashi, Worker Discontent, Voice, and EI Programs in Japan

234 Masami Imai, Market Discipline and Deposit Insurance Reform in Japan

233 Takatoshi Ito and Hugh Patrick, Problems and Prescriptions for the Japanese Economy: An Overview

232 Franklin R. Edwards, New Proposals to Regulate Hedge Funds: SEC Rule 203(b)(3)-2

231 Takatoshi Ito and Frederic Mishkin, Monetary Policy in Japan: Problems and Solutions

230 Hugh Patrick, The Japanese Recovery and Growth Not Yet Assured

2004

229 Takatoshi Ito, Interventions and Japanese Economic Recovery

228 Christian Broda and David E.Weinstein, Happy News from the Dismal Science: Reassessing Japanese Fiscal Policy and Sustainability

227 Robert A. Madsen, What Went Wrong Aggregate Demand, Structural Reform, and the Politics of 1990s Japan

226 Michael Smitka, Japanese Macroeconomic Dilemmas The Implications of Demographics for Growth and Stability

225 Lee Branstetter, Is Foreign Direct Investment a Channel of Knowledge Spillovers? Evidence from Japan's FDI in the United States

224 Jie Gan, Collateral Channel and Credit Cycle: Evidence from the Land Price Collapse in Japan

223 Chung I. Wang, The financial strategies of Japanese multinational enterprises and internal capital market

222 Donald Davis and David Weinstein, A Search for Multiple Equilibria in Urban Industrial Structure
221 Christina Ahmadjian and Jaeyong Song, Corporate Governance Reform in Japan and South Korea

220 Hugh Patrick, Evolving Corporate Governance in Japan

219 Minako Fujiki, Inflation Targeting Discussions in Japan - unconventional monetary policy under deflation: How People Have Argued; Why the BoJ Opposes Adoption

218 Adam Posen and Kenneth Kuttner, The Difficulty of Discerning What's Too Tight: Taylor Rules and Japanese Monetary Policy

217 Adam Posen, It Takes More Than a Bubble to Become Japan

216 Naotaka Kawakami, The difference in taxation on financial transactions between Japan and the United States: Can the U.S. system and theory be the model?

215 Naotaka Kawakami, What Does the Consumption Tax Mean to Japanese and U.S. Society?

214 Tokuo Iwaisako, Stock Index Autocorrelation and Cross-autocorrelations of the Size-Sorted Portfolios in the Japanese Market

213 Minoru Kobayashi, Takeshi Hiromatsu, Naoki Tsubone, Manabu Kurita, and Gosei Ohira, Economical Impacts on IT to Industries in Japan

212 William V. Rapp and Mazhar ul Islam, Putting E-Commerce to Work: The Japanese Convenience Store Case

211 Mark J. Scher, Policy Challenges and the Reform of Postal Savings in Japan

210 Takao Kato and Katsuyuki Kubo, CEO Compensation and Firm Performance in Japan: Evidence from New Panel Data on Individual CEO Pay

209 Lee Branstetter and Yoshiaki Nakamura, Has Japan's Innovative Capacity Declined?

208 David O. Beim, Japan's Internal Debt

207 Kengo Inoue, Choices for Japanese Fiscal Policy

206 Takero Doi and Takeo Hoshi, Paying for the FILP

205 Terutomo Ozawa, Pax-Americana-led MacroClustering and Flying-Geese Style Catch-Up in East Asia: Mechanisms of Regionalized Endogenous Growth

204 Robert Dekle and Heajin Ryoo, Exchange Rate Fluctuations, Financing Constraints, Hedging, and Exports: Evidence from Firm Level Data

203 Christina Ahmadjian and Gregory Robbins, A Clash of Capitalisms: Foreign Shareholders and Corporate Restructuring in 1990s Japan

202 David Flath and Tatsuhiko Nariu, Parallel Imports and the Japan Fair Trade Commission

201 David Flath, Taxicab Regulation in Japan

200 David Flath, The Japanese Distribution Sector in Economic Perspective: The Large Store Law and Retail Density 
199 David Flath, Distribution Keiretsu, FDI and Import Penetration in Japan

198 Yasushi Hamao, Jianping Mei, and Yexiao Xu, Idiosyncratic Risk and Creative Destruction in Japan

197 Hee-Joon Ahn, Jun Cai, Yasushi Hamao, and Richard Y.K. Ho, The Components of the Bid-Ask Spread in a Limit-Order Market: Evidence from the Tokyo Stock Exchange

196 Donald R. Davis and David E. Weinstein, Technological Superiority and the Losses From Migration

195 Linda Edwards and Margaret Pasquale, Women's Higher Education in Japan: Family Background, Economic Factors, and the Equal Employment Opportunity Law

194 Andrew Carverhill and Ronald Schramm, International Market Segmentation, and the CME Quanto Nikkei Future

193 Terutomo Ozawa, The hidden side of the flying geese catch-up model: Japan's dirigiste institutional setup and a deepening financial morass

192 Donald Davis and David Weinstein, Bones, Bombs and Break Points: The Geography of Economic Activity

191 William V. Rapp, Nationwide Financial Services

190 Lee Branstetter, Is Foreign Direct Investment a Channel of Knowledge Spillovers? Evidence from Japan's FDI in the U.S.

189 Christina Ahmadjian and Patricia Robinson, Downsizing and the Deinstitutionalization of Permanent Employment in Japan

188 Christina Ahmadjian, Changing Japanese Corporate Governance

187 Kazuo Sato, From Fast to Last: The Japanese Economy in the 1990s

186 Hugh Patrick, From Cozy Regulation to Competitive Markets: The Regime Shift of Japan's Financial System

185 Takao Kato, The End of Lifetime Employment in Japan? Evidence from National Surveys and Field Research

184 Takao Kato, The Recent Transformation of Participatory Employment Practices in Japan

183 William Rapp, Nomura Research Institute

182 Robert Dekle, Demographic Destiny, Per Capita Consumption, and the Japanese Saving-Investment Balance

2000

181 Maria Vassalou, The Fama-French factors as proxies for fundamental economic risks

180 Yasushi Hamao and Jianping Mei, Living With the "Enemy": An Analysis of Foreign Investment in the Japanese Equity Market

179 Yasushi Hamao and Takeo Hoshi, Bank Underwriting of Corporate Bonds: Evidence from Japan after the Financial System Reform of 1993.

178 William Rapp, International Retail Banking: The Citibank Group

177 William Rapp, Automobiles: Toyota Motor Corporation

176 Shingo Nakazawa, Corporate Investment in Japan: How Important are Financial Factors?

175 Nobuyoshi Yamori \& Narunto Nishigaki, Electronic Money Projects in Japan

174 William Rapp, Steel: Nippon Steel, K.K.
173 Nobuhiko Hibara, Food Retailing: Ito-Yokado Group

172 William V. Rapp, Steel: Tokyo Steel, K.K.

171 Yasushi Hamao, Frank Packer \& Jay Ritter, Institutional Affiliation and the Role of Venture Capital: Evidence from Initial Public Offerings in Japan

170 William V. Rapp, Retail Banking: Sanwa Bank

169 William V. Rapp, Life Insurance: Meiji Life, K.K.

168 Robert Dekle \& Koichi Yamada, On the Development of Rotating Credit Associations in Japan

167 Kazuo Sato, Japan at a Crossroads

166 Kazuo Sato, Japanese-Style Capitalism

165 David Weinstein and Robert Lawrence, Trade and Growth: Import-Led or Export-Led? Evidence from Japan and Korea

164 David Weinstein, Historical, Structural, and Macroeconomic Perspectives on the Japanese Economic Crisis

163 Hiroshi Amari, Pharmaceuticals: Takeda

162 Christos Cabolis, Semiconductors: NEC

1998

161 Hiroshi Amari, Pharmaceuticals: Merck

160 William V. Rapp, Gaining and Sustaining Long-Term Advantage Through Information Technology: The Emergence of Controlled Production

159 Mark Tilton, Antitrust Policy and Japan's International Steel Trade

158 Takao Kato, Participatory Employment Practices in Japan: Past, Present and Future

157 Ulrike Schaede, Self-Regulation and the Sanctuary Strategy: Competitive Advantage through Domestic Cooperation by Japanese Firms

156 Mariko Sakakibara, Knowledge Sharing in Cooperative Research and Development

155 Shigeru Asaba and Marvin Lieberman, Why Do Firms Behave Similarly? A Study on New Product Introduction in the Japanese Soft-Drink Industry

154 Hiroshi Ishida, Kuo-Hsien Su and Seymour Spilerman, Models of Career Progression in Japanese and U.S. Organizations

153 Hugh Patrick, Japan's Economic Misery: What Next?

152 David Flath, Japanese Technology Policy

151 David Flath, A Perspective on Japanese Trade Policy and Japan-US Trade Friction

150 David Flath, Japan's Labor Unions

149 David Flath \& Tatsuhiko Nariu, Demand Uncertainty and Price Maintenance

148 Frederic S. Mishkin, Promoting Japanese Recovery

147 Hugh Patrick, Why I Expect Japan to Prevail: Ruminations on Morishima

146 Hugh Patrick, The Causes of Japan's Financial Crisis

145 Ryoichi Mikitani and Patricia Hagan Kuwayama, Japan's New Central Banking Law: A Critical View

144 Koichi Hamada, The Japanese Big Bang as a Unilateral Action

143 Ellie Okada, Financial Control through Japan's Main Bank System and the Japanese Accounting System

142 Edward J. Lincoln, Japan's Economic Mess

141 Hugh Patrick, The Development of Studies of the Japanese Economy in the United States: A Personal Odyssey 
1997

140 Shigeyuki Goto, Study on the Interactive Approach between Insurance and Capital Markets for Catastrophe Risks

139 Patricia Hagan Kuwayama, Postal Banking in the United States and Japan: A Comparative Analysis

138 Christina L. Ahmadjian, Network Affiliation and Supplier Performance in the Japanese Automotive Industry

137 Christina L. Ahmadjian \& James R. Lincoln, Changing Firm Boundaries in Japanese Auto Parts Supply Networks

136 Fumio Hayashi, The Main Banking System and Corporate Investment: An Empirical Reassessment

135 Yasushi Hamao \& Takeo Hoshi, Bank Underwriting of Corporate Bonds: Evidence from Japan after 1994

134 Klaus Wallner, Implicit Contracts between Regulator and Firms: The Case of Japanese Casualty Insurance

133 Klaus Wallner, Commodity Bundling in Japanese NonLife Insurance: Savings-Type Products as Self-Selection Mechanism

132 Patricia Hagan Kuwayama, Credit Channels and the Small Firm Sector in Japan

131 Terry A. Marsh \& Jean-Michel Paul, BIS Capital Regulations and Japanese Bank's Bad Loan Problems

130 Yoshinobu Shiota, Update on Japanese Bad Debt Restructuring

129 Christina L. Ahmadjian, Japanese Auto Parts Supply Networks and the Governance of Interfirm Exchange

128 Takatoshi Ito, Richard K. Lyons \& Michael T. Melvin, Is There Private Information in the FX Market? The Tokyo Experiment

1996

127 Yukiko Ohara, Japan's Banking: The Darkest Hour Before Dawn. The Future is in the Hands of MoF

126 Yasushi Hamao \& Narasimhan Jegadeesh, An Analysis of Bidding in the Japanese Government Bond Auctions

125 Terry A. Marsh \& Jean-Michel Paul, Japanese Banks' Bad Loans: What Happened?

124 Hirotaka Yamauchi \& Takatoshi Ito, Air Transport Policy in Japan

123 Shinji Takagi, The Japanese System of Foreign Exchange and Trade Control, 1950-1964

122 David E. Weinstein, Foreign Direct Investment and Keiretsu: Rethinking US and Japanese Policy

121 Masatsugu Tsuji, Deregulation and Privatization of the Fiscal Investment and Loan Program

120 Koichi Hamada, Consumers, the Legal System and Product Liability Reform: A Comparative Perspective between Japan and the United States

119 David Flath, Japanese Regulation of Truck Transport

118 C.R. McKenzie, The Commercial Paper Market in Japan

117 Hideo Taki, The Gas Industry in Japan

116 Merit E. Janow, Policy Approaches to Economic Deregulation and Regulatory Reform

115 Arthur J. Alexander, Domestic Aviation in Japan: Responding to Market Forces Amid Regulatory Constraints

114 D. Eleanor Westney, The Japanese Business System: Key Features and Prospects for Change

113 Robert Dekle, Endaka and Japanese Employment Adjustment
112 G. Andrew Karolyi \& René M. Stulz, Why do Markets Move Together? An Investigation of U.S.Japan Stock Return Comovements

111 Jun-Koo Kang \& René M. Stulz, Why is There a Home Bias? An Analysis of Foreign Portfolio Equity Ownership in Japan

110 Takeo Hoshi, Bank Organization and Screening Performance

109 John W. Cooney, Jr., Kiyoshi Kato \& James S. Schallheim, Public Placements of Seasoned Equity Issues in Japan

108 Jun Cai, K.C. Chan \& Takeshi Yamada, The Performance of Japanese Mutual Funds

107 Jun-Koo Kang \& Takeshi Yamada, The Japanese Market for Corporate Control and Managerial Incentives

106 Ravi Jagannathan, Keiichi Kubota \& Hitoshi Takehara, The CAPM with Human Capital: Evidence from Japan

105 Schon Beechler, Michelle Najjar Kristen Stucker \& Allan Bird, Japanese-style versus American-style Human Resource Management Overseas: Examining Whether the Data Support the "Facts"

104 Schon Beechler, Scott Shane \& Sully Taylor, Ware Ware Nihonjin But We're Not All Alike: How Japanese Managers Champion Innovation

103 Schon Beechler \& Michelle Krazmien, The Relationship Between Expatriates, Parent CompanyAffiliate Integration and HRM Control in Overseas Affiliates of Japanese and American MNCs

102 Schon Beechler, Michelle Najjar, B.C. Ghosh, Sukiswo Dirdjosuparto \& Sieh Mei Ling, Influences on Affiliate HRM Systems in Japanese MNCs in Southeast Asia

101 Schon Beechler, John Stephan, Vladimir Pucik \& Nigel Campbell, Decision Making Localization and Decentralization in Japanese MNCs: Are There Costs of Leaving Local Managers Out of the Loop?

\section{5}

100 Yasushi Hamao, Living with the "Enemy": An Analysis of Foreign Investment in the Japanese Equity Market

99 Yasushi Hamao, Japanese Government Bond Auctions: The U.S. Experience

98 Hugh Patrick, Crumbling or Transforming? Japan's Economic Success and its Postwar Economic Institutions

97 Peter Drysdale, The Question of Access to Japanese Market

96 Hugh Patrick, Northeast Asia: The Role of International and Regional Economic Institutions and Regimes

95 Kazuo Sato, Bubbles in Japan's Stock Market: A Macroeconomic Analysis

94 William V. Rapp, Software Policies and Hardware Competition: The Impact of Government, Industry and Users on the Development of Japan's Software Industry

93 David Flath, The Keiretsu Puzzle

92 Seymour Spilerman, Hiroshi Ishida \& Kuo-Hsien Su, Educational Credentials and Promotion Prospects in a Japanese and an American Organization 
1994-1991

91 Seymour Silerman, Hiroshi Ishida, Stratification and Attainment in a Large Japanese Firm

90 Yasushi Hamao \& Joel Hasbruck, Securities Trading In the Absence of Dealers

89 Fumio Hayashi, Japan's Saving Rate: An Update

88 Frank Packer, The Disposal of Bad Loans in Japan: A Review of Recent Policy Initiatives

87 Anthony Iaquinto, Can Winners be Losers? The Case of the Deming Prize for Quality and Performance among Large Japanese Manufacturing Firms

86 C. Tait Ratcliffe, Medium-Term Prospects for the Japanese Economy and for U.S.-Japan Relations

85 Mark Scher \& Schon Beechler, Japanese Banking in the U.S.-From Transient Advantage to Strategic Failure

84 Schon Beechler, Scott Shane \& Sully Taylor, Organizational Variation in Championship Behavior: The Case of Japanese Firms

83 Schon Beechler \& Tony Iaquinto, A Longitudinal Study of Staffing Patterns in U.S. Affiliates of Japanese Multinational Corporations

82 Takatoshi Ito, Short-run and Long-run Expectations of Dollar/Yen Exchange Rate

81 Edward Lincoln, Fundamental Issues in the United States-Japan Economic Relationship

80 Fumio Hayashi, Is the Japanese Extended Family Altruistically Linked?

79 Schon Beechler \& Sheri Ranis, The Prospects for Industrial Cooperation Between the United States and Japan

78 Marcus Noland, US - Japan Trade Friction

77 Frank Packer, The Role of Long-Term Credit Banks Within the Main Bank System

76 John Campbell \& Yasushi Hamao, Changing Patterns in Corporate Financing and the Main Bank System in Japan

75 Hugh Patrick, The Relevance of Japanese Finance and its Main Bank System

74 Michael Smitka, Contracting Without Contracts: How the Japanese Manage Organizational Transactions

73 Takatoshi Ito \& Keiko Nosse Hirono, The Efficiency of the Tokyo Housing Market

72 David Flath \& Tatsuhiko Mariu, Is Japan's Retail Sector Truly Distinctive?

71 Linda Edwards, The Status of Women in Japan: Has the Equal Opportunity Law Made a Difference?

70 David Flath, Keiretsu Shareholding Ties: Antitrust Issues

69 Yasushi Hamao \& Joel Hasbrouck, Securities Trading in the Absence of Dealers: Trades and Quotes on the Tokyo Stock Exchange

68 Schon Beechler \& Allan Bird, The Transfer of Human Resource Management Overseas: An Exploratory Study of Japanese and American Maquiladoras

67 Charles Hall, Yasushi Hamao, \& Trevor Harris, A Comparison of Relations Between Security Market Prices, Returns and Accounting Measure $s$ in Japan and the US.

66 Schon Beechler \& Allan Bird, The Best of Both Worlds? An Exploratory Study of Human Resource Management Practices in US Based Japanese Affiliates

65 Michael Smitka, The Decline of the Japanese Automobile Industry: Domestic and International Implications
64 Hugh Patrick, Comparisons, Contrasts, and Implications from the Financial Development of Japan, Korea and Taiwan

63 Theodore C. Bestor, Visible Hands: Auctions and Institutional Integration in the Tsukiji Wholesale Fish Market, Tokyo

62 Frank Packer \& Marc Ryser, The Governance of Failure: An Anatomy of Corporate Bankruptcy in Japan

61 William Rapp, Japanese Multinationals: An Evolutionary Theory and Some Potential Global Political Implications for the 1990's

60 David Flath \& Tatsuhiko Nariu, The Complexity of Wholesale Distribution Channels in Japan

59 David Flath, Indirect Shareholding Within Japan's Business Groups

58 Tatsuo Hatta \& Toru Ohkawara, Commuting and Land Prices in the Tokyo Metropolitan Area.

57 John Campbell \& Yasushi Hamao, Predictable Stock Returns in the United States and Japan: A Study of Long-Term Intergration

56 Hugh Patrick, Peace and Security on the Korean Peninsula: Reflections on the Economic Dimension

55 Yasushi Hamao \& Ronald Masulis, The Effect of the 1987 Stock Crash on International Financial Integration

54 Anthony L. Iaquinto, Japanese Investment in the Border Region of the United States and Mexico

53 John Campbell \& Yasushi Hamao, Monetary Policy and the Term Structure of Interest Rates in Japan

52 Robert Dekle, Alternative Estimates of Japanese Saving and Comparisons with the US

51 Ellen R. Auster, Penetration Without Dependence: A Network Analysis of Japanese Economic Activity in the U.S.

50 Hugh Patrick, Japan's Financial System and the Evolving Role of Main Banks

49 Anthony L. Iaquinto \& Schon L. Beechler, The Performance Implications of Asset versus Transactional Advantages of MNEs

\section{0}

48 Ross Garnaut, The Market and the State in Economic Development: Some Questions from East Asia and Australia

47 Kazuo Sato, Japan's Resource Imports

46 Hugh Patrick, Section 301 and the U.S. Japan Economic Relationship: Reflections on Kuroda

45 Louis K.C. Chan, Yasushi Hamao \& Josef Lakonishok, Fundamentals and Stock Returns in Japan

44 Peter Drysdale, Change and Response in Japan's International Economic Policy

43 David Flath, Shareholding Interlocks in the Keiretsu, Japan's Financial Groups

42 Edward J. Lincoln, The Controversy Over Japan's Low Manufactured Imports

41 Edward J. Lincoln, Japan's Role in Asia Pacific Cooperation: Dimension, prospects, and Problems

40 Ellen R. Auster, Bringing a Network Perspective into Research on Technological Transfers and Other Interorganizational Relationships

\section{9}

39 Hong W. Tan \& Atsushi Seike, Pensions and Labor Turnover in Japan

38 Maurice J. Wilkinson, Inventory Behavior and Economic Instability in Japan 
37 Michael J. Smitka, American Management: Reform or Revolution? The Transfer of Japanese Management Technology to the U.S.

36 Koichi Hamada, The Causes and Consequences of Japan's High Savings Ratio

35 Ellen R. Auster, The Relationship of Industry Evolution to Patterns of Technology Linkages, Joint Ventures, and Direct Investment Between the U.S. and Japan

34 Masako N. Darrough \& Trevor S. Harris, Do Management Forecasts of Earnings Affect Stock Prices in Japan?

33 Phillip A. Klein \& Geoffrey H. Moore, Analyzing Leading and Coincident Indicators for Pacific Basin Countries

32 Geoffrey H. Moore \& John P. Cullity, Growth Cycle Signals as Inflation Indicators for Major Industrial Nations

31 Takatoshi Ito, Foreign Exchange Rate Expectations: Micro Survey Data

30 Takatoshi Ito, Is the Bank of Japan a Closet Monetarist?

29 David Flath, The Economic Rationality of the Japanese Distribution System

28 Hugh Patrick, Declining Industries, Mechanism of Structural Adjustment and Trade Policy in Pacific Basin Economics

27 Susuma Fukuda, The Fiscal Investment and Loan System

26 Shoichi Saba, The Japanese Cooperation and its Management

25 Peter Drysdale \& Ross Garnaut, A Pacific Free Trade Area?

24 James Moore Jr., The United States and Japan: Competition and Cooperation

23 Akio Mikuni, Japan's Financial Power]

22 Ariyoshi Okumura, The Future Role of Tokyo's Financial Market

21 Robert Dekle, The Relationship Between Defense Spending and Economic Performance in Japan

20 Hugh Patrick, Explaining the Japanese Financial System: A Review of the Bank of Japan's Recent Volume

19 Mototada Kikkawa, Problems of the U.S. Trade Structure
18 Hugh Patrick \& Frances Rosenbluth, Japan's Industrial Structure in Crisis: National Concerns and International Implications

17 David Flath, Why are There So Many Retail Stores in Japan?

16 Richard Baldwin, Some Empirical Evidence on Hysteresis in Aggregate U.S. Import Prices

15 Frances Rosenbluth, The Political Economy of Internationalizing the Japanese Financial System: The Case of the Bond Market

14 Robert Dekle, Do the Japanese Elderly Reduce Their Total Wealth?

\section{7}

13 Yoshio Higuchi, A Comparative Study of Japanese Plants Operating in the U.S. and American Plants: Recruitment, Job Training, Wage Structure and Job Separation

12 Jacob Mineer \& Yoshio Higuchi, Wage Structures and Labor Turnover in the U.S. and in Japan

11 Fumio Hayashi \& Takatoshi Ito, Housing Finance Imperfections and Private Saving: A Comparative Simulation Analysis of the United States and Japan

10 Hugh Patrick, The Management of the United StatesJapan Trade Relationship and its Implications for the Pacific Basin

9 Michael Smitka, Japanese Labor Market and Subcontracting

8 Takatoshi Ito, The Intra-Daily Exchange Rate Dynamics and Monetary Policies after the G5 Agreement

7 Yoshio Higuchi, Labor Force Withdrawal, Re-entry and Wages by Educational Attainment in Japanese Women

6 Kazuo Sato, Savings and Investment in Japan

5 Koichi Hamada \& Hugh Patrick, Japan and the International Monetary Regime

1986

4 Kazuo Sato, Econometric Models of the Japanese Economy

3 Hugh Patrick \& Thomas Rohlen, Japan's Small-Scale Family Enterprises

2 Richard Baldwin \& Paul Krugman, Market Access and International Competition: A Simulation Study of 16K Random Access Memories

1 Hugh Patrick, Japanese High Technology Industrial Policy in Comparative Context

\section{OCCASIONAL PAPERS}

56 Shigeyuki Goto, A Behavioral Risk Management System

55 Shigeyuki Goto \& Hiroshi Hayakawa, Building the corporate risk control system with some viewpoints on the risk psychology

54 Ryozo Hayashi, Economic Reform: View from METI
53 Junji Narita, The Economic Consequences of the 'Price Keeping Operation' in the Japanese Stock Markets

52 Shigeyuki Goto, Non-Life Insurance, E-Commerce, and the Importance of Proper Risk Communication

51 Hugh Patrick, Japan's Mediocre Economic Performance Persists and Fundamental Problems Remain Unresolved

50 Takao Sase, The Irresponsible Japanese Top Management Under the Cross-Shareholding Arrangement 
49 Naotaka Kawakami, The Impact of the Post Cold War Crises on the Political Economy of Japan

48 Yasuhisa Shiozaki, Can Japan's Ailing Banking System Be Cured?

47. Shigeyuki.Goto, E-Commerce in the Japanese NonLife Insurance Market

46 Yasushi Ueno, Effectiveness and Importance of Leadership in the Changing Period

45 Yotaro Kobayashi, Japan's Changing Corporate Structure

44 Shunji Fukukawa, Japan's Challenge for Economic Revitalization

43 Patricia Hagan Kuwayama, Lessons from Bad Experience with Banking Systems: The United States and Japan

42 Junichi Ujiie, Investment Banking in Japan

41 Toyoo Gyohten, The Japanese Financial System: Restructuring for the Future

40 William E. Franklin, Careers in International/Asia Pacific Business: Perspectives of an Experienced Japan Hand

39 Jay W. Chai, Wounded Asia vs. the IMF: Where do we go from here?

38 Lawrence H. Summers, The US-Japanese Stake in a Free and Open Asian Capital Market

37 Yuichiro Nagatomi, The Challenges Before Industrialized Countries

36 Henry Kaufman, The Yen, The Dollar and The Euro

35 Yuji Suzuki, Strategy Towards the "Big Bang" The Industrial Bank of Japan's Approach

34 Maryann Keller, International Automobile Production: How Will Firms Compete in the 21st Century?

33 Hugh Patrick, How the Japanese Financial System and Its Main Bank System Have Dealt with Generic Issues of Financial Banking

32 Patricia Hagan Kuwayama, Comments on Japanese Economic Policy

31 Roger M. Kubarych, The Yen and the Dollar: Irrational Exuberance?

30 Robert Pitofsky, Competition Policy in Communications Industries: New Antitrust Approaches

29 Masaya Miyoshi, Japan's Capitalism in Systemic Transformation

28 Yasuo Kanzaki, Japan's “Super” Big Bang: Hashimoto's Make-or-Break Gamble
27 Sheldon Weinig, Can an American Entrepreneur Work for a Japanese Company and Be Effective and Happy?

26 Takeshi Nagano, The History and Future of Japanese Management

25 Isao Matsuura, Japanese Banks in Transition: Problems and Prospects

24 Max C. Chapman, Jr., A Viable Strategy for Japanese Securities Firms in the United States

1995-1991

23 Yotaro Kobayashi, The Japanese Corporation in Transition: Current Challenges and Outlook

22 Hideo Ishihara, Re-evaluating the Japanese Corporate System

21 Yoshitaka Fujitani, Challenges Facing Japanese Steel in Today's Global Economy

20 Kenichi Ohmae, Japanese Corporate Strategy in Crisis

19 Shijuro Ogata, The Japanese Economy and the Aftermath of Its Unusual Recession

18 Jeffrey Garten, U.S.-Japan Relations: Accomplishments, Next Steps, Future Considerations

16 Susumu Yoshida, Agenda for Japanese Business in the Global Economy

15 Saburo Okita, Japan's Role in a Changing World Economy

14 Takeo Siina, Selling IBM in Japan, Selling Japan in IBM

13 Hugh Patrick, Some Thoughts on Japan's Financial Mess

12 Yoshitoki Chino, A Monologue on Japan's Financial Market

11 Jeffrey Garten, Thinking About World Order: America, Japan and Germany in the 1990's

10 Nobuo Ohashi, Innovation and Technical Development in the Japanese Steel Industry

9 Yuzaburo Mogi, Problems and Solutions to Japanese Investment Abroad

8 Hugh Patrick, One World, Two Worlds or Three? Reflections on the New International Economic Order

7 Kensuke Hotta, Deregulation of the Japanese Financial Markets and the Role of Japanese Banks

6 Hironobu Shibuya, Taking Responsibility: Japanese Companies and Corporate Citizenship

5 Sam Kusumoto, Going Global Without Going Broke

$1990-1989$

4 Yuchichiro Nagatomi, The Financial System and Global Socioeconomic Change

3 Yoshio Terasawa, The M.I.G.A. and its Mission

2 Eiji Umene, The United States-Japan Relationship in the Rapidly Changing World Environment

1 Nobutoshi Akao \& Joseph A. Massey, Agenda for a Pacific Partnership: A Japanese-American Dialogue 


\section{CENTER ON JAPANESE ECONOMY AND BUSINESS \\ Working and Occasional Papers \\ Order Form}

Many of our Working \& Occasional Papers are now available for you to download for free from our website: http://www.gsb.columbia.edu/japan. From the Center's home page choose "Publications".

To order hard copies of working paper(s) and/or occasional paper(s), please fill out this form and return it to the address below with a check made payable to the Columbia University. Papers are $\$ 5$ each.

Center on Japanese Economy and Business

Attn.: Jeff Lagomarsino

Columbia Business School

321 Uris Hall

3022 Broadway

New York, NY 10027

Title of paper(s) ordered: (Paper \#) No. of copies

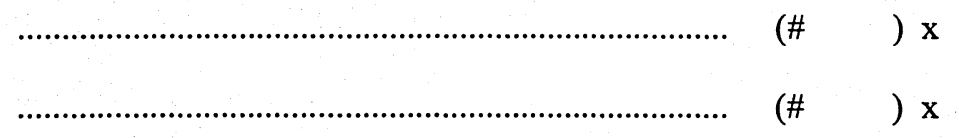

Total Cost:

$\$ 5 \mathrm{x}$ $=\$$

Please provide the address to which the paper(s) should be mailed (please print):

Name:

Affiliation:

Address:

Tel:

Fax: 